\title{
MENGGALI KEMAMPUAN AKADEMIK PESERTA DIDIK MELALUI APLIKASI MULTIPLE INTELEGENSI DALAM PROSES PEMBELAJARAN
}

\author{
Oleh : \\ Fransisca Valeria Sunartini \\ MKU- UNY \\ ( email: Fransiscadenok@yahoo.co.id)
}

\begin{abstract}
Abstrak : Pendidikan mempunyai peranan penting dalam mendukung keberhasilan seseorang dalam meraih kesuksesan. Pentingnya pendidikan ini mendorong pemerintah senantiasa melakukan perubahan kurikulum untuk mengakomodasikannya dengan kebutuhan peserta didik. Kendala utama dunia pendidikan saat ini adalah banyaknya instansi pendidikan yang menerapkan pola pikir tradisional dalam menjalankan proses belajar mengajar. Prestasi anak didik hanya diukur dari kemampuan matematika dan bahasa. Pola ini tidak mampu menghasilkan lulusan yang berkualitas. Mengingat kecerdasan intelektual tidak hanya mencakup dua parameter tersebut, maka sistem pendidikan nasional yang mengukur tingkat kecerdasan anak didik hanya menekankan pada kemampuan logika dan bahasa perlu direvisi. Kecerdasan intelektual juga harus dilihat dari aspek kinestetis, musikal, visual-spatial, interpersonal, intrapersonal, dan naturalis, atau yang biasa disebut dengan Multiple Intelligences. Multiple Intelligences yang menc.akup delapan kecerdasan itu pada dasarnya merupakan pengembangan dari kecerdasan otak (IQ), kecerdasan emosional (EQ), kecerdasan spiritual (SQ). Penerapan metode ini sebaiknya dilakukan oleh segenap tenaga kependidikan yang bekerjasama dengan orang tua, bersinergi untuk mengembangkan berbagai jenis kecerdasan pada anak didik di dalam proses belajar yang dilaksanakan di lingkungan lembaga pendidikan. Melalui penerapan metode ini kemampuan dan potensi akademik anak akan tergali dan terbina sejak dini.
\end{abstract}

Kata Kunci : Multiple Intelegensi, Peserta didik, Proses Pembelajaran.

\section{Pendahuluan}

Pendidikan adalah hal yang sangat penting untuk diperoleh anak-anak ataupun orang dewasa. Pendidikan menjadi salah satu modal bagi seseorang agar dapat berhasil dan mampu meraih kesuksesan dalam kehidupannya. Mengingat akan pentingnya pendidikan, maka pemerintah pun mencanangkan program wajib belajar 9 tahun, melakukan perubahan kurikulum untuk mencoba mengakomodasi kebutuhan peserta didik. Kesadaran akan pentingnya pendidikan bukan hanya dirasakan oleh pemerintah, tetapi juga kalangan swasta yang mulai melirik dunia pendidikan dalam mengembangkan usahanya. Sarana untuk memperoleh pendidikan yang disediakan oleh pemerintah masih dirasakan sangat kurang dalam upaya memenuhi kebutuhan masyarakat akan pendidikan. Hal ini terlihat dengan 
semakin menjamurnya sekolah-sekolah swasta yang dimulai dari Taman Kanak-Kanak sampai Perpendidikan Tinggi.

Kendala bagi dunia pendidikan untuk menghasilkan lulusan yang berkualitas adalah masih banyaknya instansi pendidikan yang mempunyai pola pikir tradisional di dalam menjalankan proses belajarnya yaitu sekolah hanya menekankan pada kemampuan logika (matematika) dan bahasa. Kenyataan ini senada dengan yang diungkapkan oleh Seto Mulyadi (2003), seorang praktisi pendidikan anak, bahwa suatu kekeliruan yang besar jika setiap kenaikan kelas, prestasi anak didik hanya diukur dari kemampuan matematika dan bahasa. Dengan demikian sistem pendidikan nasional yang mengukur tingkat kecerdasan anak didik yang semata-mata hanya menekankan kemampuan logika dan bahasa perlu direvisi.

Kecerdasan intelektual tidak hanya mencakup dua parameter tersebut di atas, tetapi juga harus dilihat dari aspek kinestetis, musikal, visual-spatial, interpersonal, intrapersonal, dan naturalis (Kompas, 6 Agustus 2003). Jenis-jenis kecerdasan intelektual tersebut dikenal dengan sebutan kecerdasan jamak (Multiple Intelligences) yang diperkenalkan oleh Howard Gardner padan tahun 1983. Gardner mengatakan bahwa kita cenderung hanya menghargai orang-orang yang memang ahli di dalam kemampuan logika (matematika) dan bahasa. Kita harus memberikan perhatian yang seimbang terhadap orangorang yang memiliki talenta (gift) di dalam kecerdasan yang lainnya seperti artis, arsitek, musikus, ahli alam, designer, penari, terapis, entrepreneurs, dan lain-lain.

Multiple Intelligences yang mencakup delapan kecerdasan itu pada dasarnya merupakan pengembangan dari kecerdasan otak (IQ), kecerdasan emosional (EQ), kecerdasan spiritual (SQ). Semua jenis kecerdasan perlu dirangsang pada diri anak sejak usia dini, mulai dari saat lahir hingga awal memasuki sekolah (7-8 tahun). (Kompas, 13 Oktober 2003). Yang menjadi pertanyaan terbesar, mampukah dan bersediakah setiap insan yang berkecimpung dalam dunia pendidikan mencoba untuk mengubah pola pengajaran tradisional yang hanya menekankan kemampuan logika (matematika) dan bahasa? Bersediakah segenap tenaga kependidikan bekerjasama dengan orang tua bersinergi untuk mengembangkan berbagai jenis kecerdasan pada anak didik di dalam proses belajar yang dilaksanakan di lingkungan lembaga pendidikan.

\section{Strategi Pembelajaran Multiple Intelegences}

1. Pengertian Strategi Pembelajaran

Strategi pembelajaran adalah suatu kegiatan pembelajaran yang harus dikerjakan pendidik dan peserta didik agar tujuan pembelajaran dapat dicapai secara efektif dan efisien 
Senjaya, 2008: 28). Selanjutnya, dengan mengutip pemikiran J. R David, Wina Senjaya (2008) menyebutkan bahwa dalam strategi pembelajaran terkandung makna perencanaan. Artinya, bahwa strategi pada dasarnya masih bersifat konseptual tentang keputusankeputusan yang akan diambil dalam suatu pelaksanaan pembelajaran. Dilihat dari strateginya, pembelajaran dapat dikelompokkan ke dalam dua bagian pula, yaitu: (1) exposition-discovery learning dan (2) group-individual learning (Rowntree dalam Senjaya, 2008). Ditinjau dari cara penyajian dan cara pengolahannya, strategi pembelajaran dapat dibedakan antara strategi pembelajaran induktif dan strategi pembelajaran deduktif.

2. Pengertian Intelegensi

Claparde dan Stern mengatakan bahwa intelegensi adalah kemampuan untuk menyesuaikan diri secara mental terhadap situasi atau kondisi baru. K. Buhler mengatakan bahwa intelegensi adalah perbuatan yang disertai dengan pemahaman atau pengertian. David Wechster (1986). Definisinya mengenai intelegensi mula-mula sebagai kapasitas untuk mengerti ungkapan dan kemauan akal budi untuk mengatasi tantangan-tantangannya. Namun di lain kesempatan ia mengatakan bahwa intelegensi adalah kemampuan untuk bertindak secara terarah, berfikir secara rasional dan menghadapi lingkungannya secara efektif.

William Stern mengemukakan batasan sebagai berikut: intelegensi ialah kesanggupan untuk menyesuaikan diri kepada kebutuhan baru, dengan menggunakan alat-alat berfikir yang sesuai dengan tujuannya. William Stern berpendapat bahwa intelegensi sebagian besar tergantung dengan dasar dan turunan, pendidikan atau lingkungan tidak begitu berpengaruh kepada intelegensi seseorang.

Dari batasan yang dikemukakan di atas, dapat kita ketahui bahwa:

a. Intelegensi itu ialah faktor total berbagai macam daya jiwa erat bersangkutan di dalamnya (ingatan, fantasi, penasaran, perhatian, minat dan sebagainya juga mempengaruhi intelegensi seseorang).

b. Kita hanya dapat mengetahui intelegensi dari tingkah laku atau perbuatannya yang tampak. Intelegensi hanya dapat kita ketahui dengan cara tidak langsung melalui "kelakuan intelegensinya".

c. Bagi suatu perbuatan intelegensi bukan hanya kemapuan yang dibawa sejak lahir saja, yang penting faktor-faktor lingkungan dan pendidikan pun memegang peranan. 
d. Bahwa manusia itu dalam kehidupannya senantiasa dapat menentukan tujuantujuan yang baru, dapat memikirkan dan menggunakan cara-cara untuk mewujudkan dan mencapai tujuan itu.

3. Teori-teori Intelegensi

Teori - Teori mengenai intelegensi ada beberapa macam, diantaranya:

a. Teori Two- Faktor

Inteligensi terdiri dari faktor $\mathrm{G}$ (general factor) kecerdasan umum yang berfungsi dalam setiap aktivitas mental \& faktor S (specific factors) kemampuan khusus seseorang: verbal, numerikal, mekanikal, perhatian, imajinasi, dll.(Charles Spearman).

b. Teori Primary Mental Abilities

Inteligensi terdiri sekelompok faktor (primary Mental Abilities): verbal comprehension, numerical, spasial visualization, perseptual ability, memory, reasoning \& word fluency. (L.L Thurstone).

c. Teori Triarchis

Menggambarkan proses berpikir sebagai komponen yang diklasifikasikan menurut fungsi \& sifat.

\section{Konsep Multiple Intelegensi}

Kecerdasan (intelegensi) adalah kemampuan untuk melakukan abstraksi, serta berpikir logis dan cepat sehingga dapat bergerak dan menyesuaikan diri terhadap situasi baru. Kemampuan kognitif, psikomotor, dan afektif yang dimiliki seseorang disebut dengan kecerdasan (Amri, 2008 : 49), sedangkan Howard Gardner dalam Sunaryo Kartadinata ( $2008: 6$ ) mendefinisikan kecerdasan sebagai:

a. Kemampuan memecahkan masalah yang muncul dalam kehidupan nyata.

b. Kemampuan melahirkan masalah baru untuk dipecahkan.

c. Kemampuan menyiapkan atau menawarkan suatu layanan yang bermakna dalam kehidupan kultur tertentu . 
Berdasarkan uraian di atas dapat disimpulkan bahwa kecerdasan adalah kemampuankemampuan yang dimiliki seseorang. Kemampuan-kemampuan yang dimiliki seseorang tidak akan semuanya sama dengan kemampuan-kemampuan yang dimiliki orang lain, karena kemampuan banyak jenisnya (beranekaragam), dan keanekaragaman dari kemampuankemampuan itu disebut dengan kecerdasan majemuk (multiple intelegensi).

Menurut Gardner, 1983 (dalam Linda Campbell, 2006) kecerdasan atau intelegensi yaitu:

a. Kecerdasan linguistic (Linguistik intelligence)

Adalah kemampuan untuk berfikir dalam bentuk kata-kata dan menggunakan bahasa untuk mengekpresikan dan menghargai makna yang komplek, yang meliputi kemampuan membaca, mendengar, menulis, dan berbicara.

b. Intelegensi logis-matematis (Logical matematich)

Adalah kemampuan dalam menghitung, mengukur dan mempertimbangkan proposisi dan hipotesis serta menyelesaikan operasi-operasi matematika.

c. Intelegensi Musik (Musical intelegence)

Intelegensi musik adalah kecerdasan seseorang yang berhubungan dengan sensitivitas pada pola titik nada, melodi, ritme, dan nada. Musik adalah bahasa pendengaran yang menggunakan tiga komponen dasar yaitu intonasi suara, irama dan warna nada yang memakai system symbol yang unik.

d. Intelegensi kinestetik.

Kinestetik adalah belajar melalui tindakan dan pengalaman melalui panca indera. Intelegensi kinestetik adalah kemampuan untuk menyatukan tubuh atau pikiran untuk menyempurnakan pementasan fisik. Dalam kehidupan sehari-hari dapat diamati pada actor,atlet atau penari, penemu, tukang emas, mekanik.

e. Intelegensi Visual-Spasial

Intelegensi visual-spasial merupakan kemampuan yang memungkinkan memvisualisasikan infoomasi dan mensintesis data-data dan konsep-konsep ke dalam metavor visual.

f. Intelegensi Interpersonal

Intelegensi interpersonal adalah kemampuan untuk memahami dan berkomunikasi dengan orang lain dilihat dari perbedaan, temperamen, motivasi, dan kemampuan.

g. Intelegensi Intrapersonal 
Adalah kemampuan seseorang untuk memahami diri sendiri dari keinginan, tujuan dan system emosional yang muncul secara nyata pada pekerjaannya.

h. Intelegensi Naturalis.

Adalah kemampuan untuk mengenal flora dan fauna melakukan pemilahanpemilahan utuh dalam dunia kealaman dan menggunakan kemampuan ini secara produktif misalnya untuk berburu, bertani, atau melakukan penelitian biologi.

5. Ciri - Ciri Multiple Intelegensi.

a. Kecerdasan Linguistik, umumnya memiliki ciri antara lain: suka menulis kreatif, (b) suka mengarang kisah khayal atau menceritakan lelucon, (c) sangat hafal nama, tempat, tanggal atau hal-hal kecil, (d) membaca di waktu senggang, (e) mengeja kata dengan tepat dan mudah, (f) suka mengisi teka-teki silang, (f) menikmati dengan cara mendengarkan, (g) unggul dalam mata pelajaran bahasa (membaca, menulis dan berkomunikasi).

b. Kecerdasan Matematika-Logis, cirinya antara lain: (a) menghitung problem aritmatika dengan cepat di luar kepala, (b) suka mengajukan pertanyaan yang sifatnya analisis, misalnya mengapa hujan turun?, (c) ahli dalam permainan catur, halma dsb, (d) mampu menjelaskan masalah secara logis, (d) suka merancang eksperimen untuk membuktikan sesuatu, (e) menghabiskan waktu dengan permainan logika seperti teka-teki, berprestasi dalam Matematika dan IPA.

c. Kecerdasan Spasial dicirikan antara lain: (a) memberikan gambaran visual yang jelas ketika menjelaskan sesuatu, (b) mudah membaca peta atau diagram, (c) menggambar sosok orang atau benda persis aslinya, (d) senang melihat film, slide, foto, atau karya seni lainnya, (e) sangat menikmati kegiatan visual, seperti tekateki atau sejenisnya, (f) suka melamun dan berfantasi, (g) mencoret-coret di atas kertas atau buku tugas sekolah, (h) lebih memahamai informasi lewat gambar daripada kata-kata atau uraian, (i) menonjol dalam mata pelajaran seni.

d. Kecerdasan Kinestetik-Jasmani, memiliki ciri: (a) banyak bergerak ketika duduk atau mendengarkan sesuatu, (b) aktif dalam kegiatan fisik seperti berenang, bersepeda, hiking atau skateboard, (c) perlu menyentuh sesuatu yang sedang dipelajarinya, (d) menikmati kegiatan melompat, lari, gulat atau kegiatan fisik lainnya, (e) memperlihatkan keterampilan dalam bidang kerajinan tangan seperti mengukir, menjahit, memahat, (f) pandai menirukan gerakan, kebiasaan atau prilaku orang lain, (g) bereaksi secara fisik terhadap jawaban masalah yang 
dihadapinya, (h) suka membongkar berbagai benda kemudian menyusunnya lagi, (i) berprestasi dalam mata pelajaran olahraga dan yang bersifat kompetitif.

e. Kecerdasan Musikal memiliki ciri antara lain: (a) suka memainkan alat musik di rumah atau di sekolah, (b) mudah mengingat melodi suatu lagu, (c) lebih bisa belajar dengan iringan musik, (d) bernyanyi atau bersenandung untuk diri sendiri atau orang lain, (e) mudah mengikuti irama musik, (f) mempunyai suara bagus untuk bernyanyi, $(\mathrm{g})$ berprestasi bagus dalam mata pelajaran musik.

f. Kecerdasan Interpersonal memiliki ciri antara lain: (a) mempunyai banyak teman, (b) suka bersosialisasi di sekolah atau di lingkungan tempat tinggalnya, (c) banyak terlibat dalam kegiatan kelompok di luar jam sekolah, (d) berperan sebagai penengah ketika terjadi konflik antartemannya, (e) berempati besar terhadap perasaan atau penderitaan orang lain, (f) sangat menikmati pekerjaan mengajari orang lain, (g) berbakat menjadi pemimpin dan berperestasi dalam mata pelajaran ilmu sosial.

g. Kecerdasan Intrapersonal memiliki ciri antara lain: (a) memperlihatkan sikap independen dan kemauan kuat, (b) bekerja atau belajar dengan baik seorang diri, (c) memiliki rasa percaya diri yang tinggi, (d) banyak belajar dari kesalahan masa lalu, (e) berpikir fokus dan terarah pada pencapaian tujuan, (f) banyak terlibat dalam hobi atau proyek yang dikerjakan sendiri.

h. Kecerdasan Naturalis, memiliki ciri antara lain: (a) suka dan akrab pada berbagai hewan peliharaan, (b) sangat menikmati berjalan-jalan di alam terbuka, (c) suka berkebun atau dekat dengan taman dan memelihara binatang, (d) menghabiskan waktu di dekat akuarium atau sistem kehidupan alam, (e) suka membawa pulang serangga, daun bunga atau benda alam lainnya, (f) berprestasi dalam mata pelajaran IPA, Biologi, dan lingkungan hidup.

Keunikan yang dikemukakan Gardner adalah, setiap kecerdasan dalam upaya mengelola informasi bekerja secara spasial dalam sistem otak manusia. Tetapi pada saat mengeluarkannya, ke delapan jenis kecerdasan itu bekerjasama untuk menghasilkan informasi sesuai yang dibutuhkan.

6. Faktor - Faktor yang Mempengaruhi Intelegensi.

Intelegensi tiap individu cenderung berbeda-beda. Hal ini dikarenakan beberapa faktor yang mempengaruhinya. Adapun faktor-faktor yang mempengaruhi intelegensi antara lain sebagai berikut:

a. Faktor Bawaan atau Keturunan. 
Faktor ini ditentukan oleh sifat yang dibawa sejak lahir. Batas kesanggupan atau kecakapan seseorang dalam memecahkan masalah, antara lain ditentukan oleh faktor bawaan. Oleh karena itu, di dalam satu kelas dapat dijumpai anak yang bodoh, cukup pintar dan sangat pintar, meskipun mereka menerima pelajaran dan pelatihan yang sama. Penelitian membuktikan bahwa korelasi nilai tes IQ dari satu keluarga sekitar 0,50. Sedangkan di antara 2 anak kembar, korelasi nilai tes IQnya sangat tinggi, sekitar 0,90. Bukti lainnya adalah pada anak yang diadopsi. IQ mereka berkorelasi sekitar 0,40 - 0,50 dengan ayah dan ibu yang sebenarnya, dan hanya 0,10 - 0,20 dengan ayah dan ibu angkatnya. Selanjutnya bukti pada anak kembar yang dibesarkan secara terpisah, IQ mereka tetap berkorelasi sangat tinggi, walaupun mungkin mereka tidak pernah saling kenal.

b. Faktor Minat dan Pembawaan yang Khas.

Faktor minat mengarahkan perbuatan kepada suatu tujuan dan merupakan dorongan bagi perbuatan itu. Dalam diri manusia terdapat dorongan atau motif yang mendorong manusia untuk berinteraksi dengan dunia luar,sehingga apa yang diminati oleh manusia dapat memberikan dorongan untuk berbuat lebih giat dan lebih baik. Intelegensi bekerja dalam situasi yang berlain-lainan tingkat kesukarannya. Sulit tidaknya mengatasi persoalan ditentukan pula oleh pembawaan.

c. Faktor Pembentukan atau Lingkungan.

Pembentukan adalah segala keadaan di luar diri seseorang yang mempengaruhi perkembangan intelegensi. Di sini dapat dibedakan antara pembentukan yang direncanakan, seperti dilakukan di sekolah atau pembentukan yang tidak direncanakan, misalnya pengaruh alam sekitarnya. Walaupun ada ciri-ciri yang pada dasarnya sudah dibawa sejak lahir, ternyata lingkungan sanggup menimbulkan perubahan-perubahan yang berarti. Inteligensi tentunya tidak bisa terlepas dari otak. Perkembangan otak sangat dipengaruhi oleh gizi yang dikonsumsi. Selain gizi, rangsangan-rangsangan yang bersifat kognitif emosional dari lingkungan juga memegang peranan yang amat penting.

d. Faktor Kematangan.

Tiap organ dalam tubuh manusia mengalami pertumbuhan dan perkembangan. Setiap organ manusia baik fisik mauapun psikis, dapat dikatakan telah matang, jika ia telah tumbuh atau berkembang hingga mencapai kesanggupan menjalankan fungsinya masing-masing. Oleh karena itu, tidak diherankan bila 
anak anak belum mampu mengerjakan atau memecahkan soal-soal matematika di kelas empat sekolah dasar,Karena soal soal itu masih terlampau sukar bagi anak. Organ tubuhnya dan fungsi jiwanya masih belum matang untuk menyelesaikan soal tersebut dan kematangan berhubungan erat dengan faktor umur. Kecerdasan tidak tetap statis, tetapi cepat tumbuh dan berkembang. Tumbuh dan berkembangnya intelegensi sedikit banyak sejalan dengan perkembangan jasmani, umur dan kemampuan-kemampuan yang telah dicapai (kematangannya).

\section{e. Faktor Kebebasan.}

Hal ini berarti manusia dapat memilih metode tertentu dalam memecahkan masalah yang dihadapi. Di samping kebebasan memilih metode, juga bebas dalam memilih masalah yang sesuai dengan kebutuhannya. Kelima faktor di atas saling mempengaruhi dan saling terkait satu dengan yang lainnya. Jadi, untuk menentukan kecerdasan seseorang, tidak dapat hanya berpedoman atau berpatokan kepada salah satu faktor saja.

\section{Pengaruh Intelegensi Terhadap Keberhasilan Peserta Didik.}

Intelegensi seseorang diyakini sangat berpengaruh pada keberhasilan belajar yang dicapainya. Berdasarkan hasil penelitian, prestasi belajar biasanya berkolerasi searah dengan tingkat intelegensi. Artinya, semakin tinggi tingkat intelegensi seseorang, maka semakin tinggi prestasi belajar yang dicapainya. Bahkan menurut sebagian besar ahli, intelegensi merupakan modal utama dalam belajar dan mencapai hasil yang optimal. Anak yang memiliki skor IQ dibawah 70 tidak mungkin dapat belajar dan mencapai hasil belajar seperti anak-anak dengan skor IQ normal, apalagi dengan anak-anak jenius.

Kenyataan menunjukkan bahwa setiap anak memiliki tingkat intelegensi yang berbeda-beda. Perbedaan tersebut tampak memberikan warna di dalam kelas. Selama menerima pelajaran yang diberikan pendidik, disampaikan oleh pendidik dan ada pula anak yang lamban. Perbedaan individu dalam intelegensi ini perlu diketahui dan dipahami oleh pendidik, terutama dalam hubungannya dengan pengelompokkan peserta didik. Selain itu, pendidik harus menyesuaikan tujuan pembelajarannya dengan kapasitas intelegensi peserta didik. Perbedaan intelegensi yang dimiliki oleh peserta didik bukan berarti membuat pendidik harus memandang rendah pada peserta didik yang kurang, tetapi pendidik harus mengupayakan agar pembelajaran yang 
diberikan dapat membantu semua peserta didik, tentu saja dengan perlakuan metode yang beragam.

Selain itu, perbedaan tersebut juga tampak dari hasil belajar yang dicapai. Tinggi rendahnya hasil belajar yang dicapai oleh peserta didik bergantung pada tinggi rendahnya intelegensi yang dimiliki. Meski demikian, intelegensi bukan merupakan satu-satunya faktor yang mempengaruhi keberhasilan belajar seseorang. Seperti telah dikemukakan bahwa banyak sekali faktor yang dapat mempengaruhinya. Yang terpenting dalam hal ini adalah pendidik harus bijaksana dalam menyingkapi perbedaan tersebut.

8. Program Pembelajaran yang Mengakomodasi Perkembangan Multiple Intelegensi.

Untuk menerapkan teori multiple intelegensi dalam program pembelajaran diperlukan usaha yang serius dari pendidik. Pendidik harus membiasakan diri mengembangkan program pelajaran yang berorientasi pada peserta didik bukan pada materi atau dirinya sendiri. Tujuannya adalah untuk memudahkan pendidik dalam menentukan strategi pembelajaran yang tepat yang dapat mengembangkan intelegensi peserta didik secara maksimal. Mengingat multipel intelegensi belum memasyarakat, maka hal ini akan menjadi penghambat bagi pendidik untuk memasukkannya pada saat menyusun program pembelajaran.

Program pembelajaran pengertiannya lebih luas dari kegiatan pembelajaran. Kegiatan pembelajaran terbatas pada aktivitas pendidik dan peserta didik di kelas saja, sedangkan pengertian program pembelajaran adalah menyeluruh mulai dari rencana pembelajaran, kegiatan pembelajaran sampai dengan produk hasil dari pengembangan program pembelajaran. Program pembelajaran berbentuk produk ini dapat berupa kegiatan pembelajaran langsung atau tatap muka, tetapi dapat juga berbentuk program video, audio, dan sebagainya.

Gardner menjelaskan bahwa setiap intelegensi bekerja dalam sistem otak yang relatif otonom. Artinya setiap intelegensi mengelola informasi secara parsial, namun pada saat mengeluarkannya memproduksi kembali kedelapan intelegensi yang ada, intelegensi tersebut bekerja sama secara unik untuk menghasilkan informasi yang dibutuhkan. Di dekolah, pendidik adalah orang yang berkepentingan dalam mengembangkan program-program pembelajaran dikelasnya. Dalam mengembangkannya pendidik dimungkinkan untuk mengembangkan strategi embelajaran yang inovatif dan kreatif dalam dunia pendidikan, salah satunya adalah dengan menggunakan strategi pembelajaran berbasis multipel intelegensi. 
Menurut Amstrong dalam Robinson (2004), strategi pembelajaran berbasis multipel intelegensi ini merupakan suatu upaya mengoptimalkan berbagai intelegensi yang dimiliki setiap peserta didik untuk mencapai kompetensi tertentu yang dituntut dalam kurikulum. Pada prakteknya strategi pembelajaran berbasis multipel intelegensi ini memacu kecerdasan yang menonjol pada diri peserta didik seoptimal mungkin, dan berupaya mempertahankan intelegensi lainnya pada standar minimal yang dituntut sekolah. Dengan kata lain, penerapan strategi multipel intelegensi dalam pengembangan program-program pembelajaran menguntungkan bagi peserta didik. Peserta didik akan berkembang sesuai dengan jati dirinya yang potensial pada salah satu atau lebih intelegensi yang dimilikinya.

Adapun langkah-langkah yang dapat digunakan dalam menerapkan strategi pembelajaran berbasis multipel intelegensi antara lain:

a. Memberdayakan semua intelegensi yang dimiliki setiap peserta didik.

Memberdayakan semua intelegensi pada setiap mata pelajaran adalah ibarat meng-input melalui jalur ke dalam otak memori peserta didik. Contoh perhatikan TIK berikut: peserta didik dapat mempelajari proses fotosintesis melalui tujuh cara/intelegensi. Intelegensi yang mencakup TIK tersebut adalah intelegensi bahasa, logis-matematis, musik, kinestik, interpersonal dan intrapersonal. Dengan demikian, tingkat belajar peserta didik akan lebih tinggi dibanding jika peserta didik hanya membaca buku atau mendengar penjelasan dari pendidik saja.

b. Mengoptimalkan pecapaian mata pelajaran tertentu berdasarkan intelegensi yang menonjol pada setiap peserta didik.

Langkah ini dapat diterapkan jika pendidik telah mengidentifikasi inteelegensi apa yang menonjol pada peserta didik-peserta didiknya. Dengan demikian strategi pembelajaran yang dipilih lebih bersifat individual atau personal. Untuk peserta didik yang lebih menonjol intelegensi bahasanya, maka pendidik harus merancang program pembelajaran yang merangsang dan mengembangkan intelegensi peserta didik dalam kemampuan berbahas, dan seterusnya.

Pada kenyataannya, pengembangan program-program pembelajaran yang merupakan teori multipel intelegensi tidaklah mudah, terutama mencakup evaluasinya. Evaluasinya harus multi asesmen artinya penilaian harus bervariasi dan dapat memberikan banyak motivasi dan merupakan penilaian yang menarik. Untuk mewujudkan evaluasi yang multipel asesmen tidaklah mudah. Dalam pembelajaran 
berbasis multipel intelegensi penilaian membatasi atau bahkan mengurangi penggunaan skor tes sebagai penilaian tunggal. Penggunaan pola-pola penilaian alternatif sehingga semua unsur mendapat perhatian yang optimal, baik tentang hasil belajar peserta didik maupun tentang pengembangan intelegensi peserta didik.

Hambatan yang mungkin dialami pendidik pada saat pengembangan program pembelajaran yang menerapkan teori multipel intelegensi, antara lain adalah sebagai berikut:

a. Pendidik belum mempunyai wawasan yang cukup tentang multipel intelegensi;

b. Pendidik butuh dukungan dari pimpinan sekolah atau pengelola sekolah untuk mengembangkan program-program pembelajaran yang berbasisi multipel intelegensi karena untuk persiapan pengembangan program pembelajaran memerlukan waktu lama serta bimbingan narasumber;

c. Dukungan dari sekolah yang belum maksimal, dalam penyediaan sarana belajar seperti alat peraga atau media pembelajaran dan ruang belajar yang kondusif dan lain-lain tergantung kegiatan-kegiatan apa yang akan dilaksanakan serta sumber materi apa yang akan digunakan.

9. Langkah Penerapan Strategi Pembelajaran Multiple Intelligences (MI)

Ada dua tahapan yang harus dilakukan dalam penerapan strategi pembelajaran MI agar mendapatkan hasil yang optimal, yaitu:

a. Memberdayakan semua jenis kecerdasan pada setiap mata pelajaran.

Memberdayakan semua jenis kecerdasan pada setiap mata pelajaran adalah ibarat meng-input informasi melalui delapan jalur ke dalam otak memori peserta didik. Bila Bloom (1956), menekankan pada tiga jalur dominan yang ada yaitu: kognitif, afektif, dan psikomotor; maka Gardner (1999), menekankan pada delapan kecerdasan yang dimiliki setiap peserta didik, yaitu:kecerdasan linguistik, matematis-logis, spasial, kinestetik-jasmani, musikal, interpersonal, intrapersonal, dan naturalis.

Secara empirik untuk menerapkan strategi pembelajaran MI dapat dimulai dengan melakukan reposisi pada kurikulum yang ada sekarang, baik itu kurikulum 1994 yang disempurnakan maupun Kurikulum Berbasis Kompetensi (KBK), Kurikulum Tingkat Satuan Pendidikan (KTSP) dan Kurikulum 2013. Hal ini dilakukan dengan cara mengubah Tujuan Instruksional Khusus (TIK) yang ada menjadi kompetensi yang diharapakan . 
Dengan demikian, setiap TIK atau pokok bahasan dituntut untuk memberdayakan semua atau sebagian besar jenis kecerdasan yang ada.

Sebagai contoh mata pelajaran bahasa yang dominan dengan kecerdasan linguistik, TIK-nya berbunyi "Peserta didik dapat membacakan puisi dengan intonasi yang benar di depan kelas”. Bila Peserta didik melakukan semua itu dengan benar; maka kecerdasan yang terlibat akan meliputi: Kecerdasan Linguistik, Matematis-Logis, Spasial Terbatas, dan Kinestetik-Jasmani saja. Akan tetapi bila TIK diubah menjadi "Peserta didik dapat membacakan puisi dengan intonasi yang benar pada acara tertentu, atau di depan publik"; maka kecerdasan yang terlibat akan banyak lagi yaitu: Kecerdasan Linguistik, Matematis-Logis, Spasial Terbatas, KinestetikJasmani, Interpersonal, Intrapersonal dan Naturalis. Dengan demikian kadar belajar yang diperoleh oleh peserta didik akan jauh lebih tinggi dibandingkan apabila ia hanya membacakan puisi di depan kelas. Pemikiran-pemikiran kreatif yang demikian inilah yang dituntut pada setiap pendidik bila ingin menerapkan strategi pembelajaran MI dalam mata pelajaran yang dikelolanya. Meskipun belum ada penelitian yang dapat menyimpulkan, apakah hasil belajar peserta didik meningkat secara signifikan, tetapi berdasarkan observasi di lapangan menunjukkan adanya perubahan dalam sikap belajar peserta didik. Peserta didik terlihat lebih aktif, percaya diri, dan kreatif dalam banyak hal.

b. Mengoptimalkan pencapaian mata pelajaran tertentu berdasarkan kecerdasan yang menonjol pada masing-masing peserta didik.

Tahapan kedua ini ditempuh apabila secara faktual pendidik telah mengidentifikasi kecerdasan yang menonjol pada masing-masing peserta didik. Sekali lagi, baik Gardner (1999), maupun Amstrong (2002), selalu mengingatkan bahwa ada satu atau lebih kecerdasan yang menonjol pada masing-masing individu (peserta didik). Bila kita menyadari hal ini, mengapa kita tidak mengoptimalkannya menjadi sesuatu yang bermakna bagi peserta didik. Atau menjadikannya sebagai jati dirinya, meskipun untuk bidang yang lainnya harus puas dengan standar minimal yang ditetapkan oleh masingmasing lembaga.

Dalam penerapan tahap kedua ini strategi pembelajaran yang digunakan lebih bersifat personal atau individual. Peserta didik yang memiliki kecerdasan Lingiustik misalnya, akan dioptimalkan pencapaian hasil 
belajarnya pada mata pelajaran Bahasa dan Sastra. Sedangkan mereka yang mempunyai kecerdasan Matematis-Logis misalnya, akan diarahkan pada pencapaian hasil belajar Matematikanya seoptimal mungkin melalui pemberian layanan individu dan akses ke berbagai kesempatan yang memungkinkan kecerdasan Matematikanya terus berkembang. Bagi mereka yang memiliki kecerdasan Spasial belajar dengan menggunakan media visual atau menggunakan peta konsep tentu sangat membantu mereka mencapai kesempurnaan belajarnya. Akan tetapi bagi mereka yang memiliki kecerdasan Kinestetik-Jasmani sangatlah tersiksa bila ia harus dipaksa duduk yang manis di dalam kelas. Mereka yang memiliki kecerdasan Kinestetik-Jasmani akan menghasilkan sesuatu secara optimal, bila mereka diizinkan belajar dengan cara melakukan gerakan-gerakan tertentu. Misalnya mengekspresikan suatu pesan dengan bahasa tubuhnya. Sedangkan belajar dengan alunan musik tentu sangat menyenangkan bagi mereka yang memiliki kecerdasan Musikal. Musik-musik klasik sangat dianjurkan sebagai pengiring bagi mereka memiliki kecerdasan Musikal ini. Dengan musik mereka akan menghasilkan sesuatu yang optimal dalam belajarnya. Lain pula halnya dengan mereka yang memiliki kecerdasan Interpersonal. Melakukan interaksi sosial adalah pilihan yang tepat bagi mereka yang memiliki kecerdasan Interpersonal ini. Sedangkan bagi mereka yang memiliki kecerdasan Intrapersonal tentulah sangat berterima kasih bila diizinkan belajar secara individual di tempat yang agak sepi, atau mengerjakanproyek individual. Untuk peserta didik yang memiliki kecerdasan Naturalis akan efektif bila diarahkan pencapaian hasil belajar yang optimal untuk mata pelajaran IPA atau Biologi. Belajar di luar kelas (outdoor) merupakan sesuatu yang menyenangkan bagi mereka yang memiliki kecerdasan Naturalis ini.

Uraian di atas adalah sekelumit contoh bagaimana strategi pembelajaran MI diimplementasikan dalam pembelajaran di sekolah. Khususnya untuk mencapai setiap kompetensi yang telah ditetapkan dalam sebuah kurikulum. Sangat jelas, bagaimana pendidik berupaya menjadikan peserta didiknya menjadi juara pada bidang tertentu sesuai dengan kecerdasan yang dimilikinya. Peserta didik tidak hanya menguasai konsep pengetahuan semata, tetapi ia juga dapat menerapkan pengetahuannya dalam berbagai aspek kehidupan. Dengan kata lain tidak ada yang mustahil bila kita ingin 
melakukan perubahan dalam strategi pembelajaran yang akan kita gunakan. Banyak jalan menuju Roma, mengapa kita tdak mencobanya.

\section{Penutup}

Kecerdasan sebagai kemampuan untuk memproses informasi sehingga masalahmasalah yang kita hadapi dapat dipecahkan (problem solved) dan dengan demikian pengetahuan pun bertambah. Jadi mudah dipahami bahwa kecerdasan adalah pemandu bagi kita untuk mencapai sasaran-sasaran kita secara efektif dan efisien. Kecerdasan merupakan suatu kemampuan untuk memahami informasi yang membentuk pengetahuan dan kesadaran. Tingkat kecerdasan (Intelegensi) ditentukan oleh bakat bawaan berdasarkan gen yang diturunkan dari orang tuanya. Secara umum intelegensi dapat dirumuskan sebagai berikut : Kemampuan memecahkan masalah yang muncul dalam kehidupan nyata. Kemampuan melahirkan masalah baru untuk dipecahkan. Kemampuan menyiapkan atau menawarkan suatu layanan yang bermakna dalam kehidupan kultur tertentu.

Menurut Gardner, 1983 kecerdasan atau intelegensi ada 8 macam yaitu:Kecerdasan linguisti, Intelegensi logis-matematis, Intelegensi Musik, Intelegensi kinestetik, Intelegensi Visual-Spasial, Intelegensi Interpersonal, Intelegensi Intrapersonal, Intelegensi Naturalis. Strategi Pembelajaran MI pada praktinya adalah memacu kecerdsan yang menonjol pada diri peserta didik supaya optimal.

\section{DAFTAR PUSTAKA}

Armstrong, T. 2004. Sekolah Para Juara: Menerapkan Multiple Intelegences di Dunia Pendidikan. Bandung : Kaifa.

Azwar, Saifuddin. 1996. Pengantar Psikologi Inteligensi. Yogyakarta: Pustaka Pelajar.

Gardner, Howard. 2003. Kecerdasan Majemuk. Batam: Interaksara.

Robert J. Stenberg. 2008. Psikologi Kognitif Edisi 4. Jakarta: Pustaka Pelajar. 